\title{
MAX STIRNER'S CRITIQUES of PIERRE-Joseph PROUdHoN
}

\section{Maurice Schuhmann}

$(\text { Berlim) })^{*}$

The works of the French early socialist Pierre-Joseph Proudhon (1809-1865) were really important for the intellectual discussions in the circle of the German young hegelians. This importance could be testified to the number of the mentions in letters, reviews and direct or indirect quotations by him - f. ex. in the works of Arnold Ruge who edited Proudhon's memoirs "Les Confessions d'un révolutionnaire pour servir à l'histoire de la Révolution de Février" in the year 1850, of Edgar Bauer who edited in the Allgemeine Literatur-Zeitung a longer article concerning to the philosophy of Proudhon in April 1844, and certainly Karl Marx who wrote later his polemic "Das Elend der Philosophie" (1846/47) about him. Also, it is verifiable, that Max Stirner absorbed intensively the works of Proudhon - especially in his main work "Der Einzige und sein Eigentum" (1844), where he mentioned the name of Proudhon 14 times. He refers in this work to "Qu'est-ce que la Propriété?"2 (1840) and "De la Création de l'ordre dans l'humanité ou principes d'organisation politique" $(1843)^{3}$, the two main works of Proudhon at this time. In both works Proudhon broached the issue of private property. Furthermore Proudhon's "Système des contradictions économiques ou Philosophie de la misère" (1846) was part of the series about "Nationaloekonomen der Franzosen und Engländer", which was edited by Max Stirner after he had published his

\footnotetext{
* Maurice Schuhmann, Grolmanstraße 17, 10623 Berlin, Deutschland, MauriceSchuhmann@aol.com / www.m-schuhmann.de.vu

${ }^{1}$ La Voix du Peuple, Paris 1849.

2 The first complete German translation of it was published in 1896 with the title "Was ist das Eigentum?" ad edition Zack in Berlin. It was already translated in digest from Bernbei ad the edition Jenny (cf. Cohn 1896, V).

${ }^{3}$ It has not been translated into German until now.
} 
main work "Der Einzige und sein Eigentum". The first eight volumes of this serial were Jean Baptiste Say ("Traite économie politique") and Adam Smith ("An Inquiry into the Nature and Causes of the Wealth of Nations") which were translated by Stirner himself. The other two volumes Proudhon's "Philosophie de la misère" - were translated by the young hegelian author Wilhelm Jordan (1818-1904) ${ }^{4}$. The Stirner-biographer John Henry Mackay wrote about this topic: "Mit dem Werke von Smith hörte die Herausgeberschaft Stirner's an seiner Sammlung auf; wohl erschien noch die Wilhelm Jordan'sche Uebersetzung von P.-J. Proudhons Philosophie de la misère, aber Stirner ist an dem Gesamtunternehmen nicht mehr beteiligt" (Mackay, 1977: 185) .

In the history of the reception of Stirner as well as in the one of Proudhon the animadversion of Stirner on Proudhon is handled as a marginal note. It is ignored completely or it is only mentioned to show that it is not able to add Stirner to the philosophical stream of anarchism ${ }^{6}$. An example is the entry of Bernd A. Laska in the "Lexikon der Anarchie": "Stirner bezeichnete sich selbst nirgendwo als Anarchisten; er kritisierte vielmehr in seinem Einzigen (1844) den Mann, der sich 1840 als erster selbst einen Anarchisten genannt hatte: Proudhon - allerdings nicht deswegen, sondern wegen seiner moralisierenden Betrachtungsweise der gesellschaftlichen Probleme" (Laska, 1993: 1)7.

Before I start to clear the examination, I should clarify the fundament of Stirner's absorption of Proudhon - especially the both main works which are mentioned in "Der Einzige und sein Eigentum". Both works were well-known in the circle of the German young hegelians. Edgar Bauer mentioned both of them in his article about Proudhon which was published in issue 5 of the "Allgemeine Literatur-Zeitung" (April 1844) edited by his brother Bruno Bauer. Stirner quoted this issue several times in his work (cf.: EE: 132, 134, 139, 148) .

${ }^{4}$ Herve-Marie Forest is mistaken, if he wrote in his work "Marx au miroir de Stirner" that the translation was made by Stirner (cf. Forest, 1979: 131).

5 "With the work of Smith the editorship of Stirner for the serial ended; it appears already a translation from P.-J. Proudhon's Philosophie de la misère, but Stirner was not any longer involved in the overall project."

${ }^{6}$ A counterexample for this is the Proudhon biographer Karl Diehl, who used Stirner as an individualist reference point to plumb the position of Proudhon in anarchism (cf. Diehl, 1968).

7 "Stirner never called himself an anarchist. He criticised in "Der Einzige und sein Eigentum" the man, who first in 1840 called himself an anarchist -Proudhon; Indeed not for this reason, but for his morally view of social problems."

8 This article was also mentioned in the polemic "Die heilige Famile" (1844) from Karl Marx and Friedrich Engels. 
The work "Qu'est-ce que la propriété?" is the first aide memoir from Proudhon. He wrote it 1840 - addressed to the members of the academy of Besançon and he lost his bursary. He analyzed the concept of (private) property from different points of view. He located it as the fundament of the state and its institutions. He formed the famous sentence - "Property is theft!". His critiques were a confrontation with the contemporary definition of property. It is often mentioned as an anticipation of the critique of Karl Marx (cf. f. ex. Roemheld, 1993: 1). He picked this topic as a central theme. For him private property is not compatible with the principal of equality. He tries to undermine this point in an interdisciplinary way. He argues:

"Le droit de propriété a eté le commencement du mal sur terre, le premier anneau de cette longue chaîne de crimes et de misères que le genre humain traîne dès sa naissance" (Proudhon, 1841: 97).

His second text "De la Création de l'ordre dans l'humanité ou principes d'organisation politique", which was written three years later is strongly influenced by the ideas of other early socialists like Charles Fourier and Saint-Simon. In this text, in which he combined religious, philosophical, economic and historical problems of the development of mankind - sometimes without a direct connection between each other - is considered the first fundamental manifestation of his philosophy. It shows a clear advance in formulating his philosophy in form of an encyclopaedia. On the other hand it is strongly orientated at the categories of Étienne Cabet, Charles Fourier and Immanuel Kant (cf. Bock, 1991: 98). Later he called it a failed work (cf. Woodcock, 1956: 76).

A first approach to the topic can be found in the analysis "Im Schatten des Einzigen. Die Geschichte des Stirnerschen Individualanarchismus" by Gerhard Senft (1988). The discussion about this topic is integrated in the analysis of Stirner's critique of the early socialists in general. Senft wrote: "Proudhon bietet in mehrfacher Hinsicht Angriffsflächen für Stirner: Der Kardinalfehler Proudhons bestehe darin, daß er es noch nicht geschafft habe, sich vom Sittengesetz loszusagen" (Senft, 1988: 53) ${ }^{9}$. Furthermore it is an animadversion on the question of property of Proudhon as well as of the German socialist Wilhelm Weitling ${ }^{10}$. I largely agree with this fragmentation but I prefer a more abstract and differentiated level.

\footnotetext{
9 "Proudhon offers on different levels a contact surface for Stirner. His cardinal error is that he didn't detached himself from the moral law."

10 Stirner addresses with his critique of the sentence "Property is theft" Proudhon as well as the German early socialist Wilhelm Weitling, whose work "Garantien der Harmonie und Freiheit" he often mentioned (cf. EE: 254, 270).
} 
The following two levels seem to me the most important ones for analysing the critique of Proudhon:

- Proudhon as a classical ambassador of "obsession", i.e. an "unconscious egoist";

- Proudhon's term of property in general.

Especially the second promises new awareness about Stirner's own term of property.

\section{Proudhon as a classical ambassador of "obsession"}

Proudhon is mentioned in three passages as an ambassador of "obsession" (cf. EE: 57, 255, 318). For example, Stirner wrote in the subchapter about "Der Sparren" ("The spook"):

"Und doch sind fast immer nur sittliche Gegner auf der Mensur erschienen, um das höchste Wesen anzufechten zu Gunsten eines andern höchsten Wesens. So sagt Proudhon ungescheut: "Der Mensch ist bestimmt, ohne Religion zu leben, aber das Sittengesetz (la loi morale) ist ewig und absolut. Wer würde es heute wagen, die Moral anzugreifen?" (EE: 57) ${ }^{11}$.

Proudhon appears in this passage as a demoniac, who bases his own thing instead of his own on an universal term. Referring to his argumentation this is a logical consequence. Proudhon is captured by a "fixed idea"; i.e., he is not a conscious egoist; he is not an owner. This kind of critiques can be applied to nearly every thinker. For this reason this point of critique delivers no new awareness about the confrontation with Stirner.

Much more relevant for an analysis seems to be the second point of the critique:

\section{Proudhon's term of property in general}

This aspect has to be splitted - on the one side it is mentioned as a critique of the "fixed idea", on the other side a discussion can be found about the splitting of this term in the parts of "property" and "right to

11 "And yet it has almost always been only moral opponents that have appeared in the arena, to assail the supreme essence in favor of - another supreme essence. So Proudhon, unabashed, says: Man is destined to live without religion, but the moral law is eternal and absolute. Who would dare today to attack morality?" (EO: 78) 
own". The critique of the term of property as a fixed idea can be found in the already mentioned quote "property is theft".

"Nun stellt sich die Sache so: Wenn ein Verbrechen auch weder Mir, noch irgend einem derjenigen, an welchen Ich Anteil nehme, den geringsten Schaden brächte, so würde Ich dennoch gegen dasselbe eifern. Warum? Weil Ich für die Sittlichkeit begeistert, von der Idee der Sittlichkeit erfüllt bin; was ihr feindlich ist, das verfolge Ich. Weil ihm der Diebstahl ohne alle Frage für verabscheuungswürdig gilt, darum glaubt z. B. Proudhon schon mit dem Satze: "Das Eigentum ist ein Diebstahl" dieses gebrandmarkt $\mathrm{zu}$ haben. Im Sinne der Pfäffischen ist er allemal ein Verbrechen oder mindestens Vergehen" (EE: 86) $)^{12}$.

Similar conclusions can also be found in other passages of Stirner's work (f. ex. EE: 255). A crime can only be committed against something foreign. The crime is a violation, what concretely means for the term of property in the idea of Proudhon that property is something sacred or foreign. For this reason it is a fixed idea in form of an ideology especially, if it is mentioned in an appeal to legislation, which means at least that the legislation is accepted. Stirner writes about the legislation: "Recht - ist ein Sparren, erteilt von einem Spuk" (EE: 215) ${ }^{13}$. At the same time the obsession of the concept of morality is really important for the concept of Proudhon's work.

Much more important for the discussion with regard to content is the concrete confrontation with the differentiation between "property" and "ownership" of Proudhon. At the beginning of his essay "Qu'est-ce que la proprieté?" he makes a basic difference between both levels. He writes:

"On distingue dans la propriété: $1^{\circ}$ la propriété pure et simple, le droit domanial, seigneurial sur la chose, ou, comme l'on dit la nue-propriété; $2^{\circ}$ la possession" (Proudhon, 1841: 37).

Such a difference is strange to Stirner. His term of property contains the material aspect which was caricatured by Karl Marx ("Die deutsche Ideologie") and later also by Hans G. Helms ("Die Ideologie der

12 "Now the matter stands thus: even if a crime did not cause the slightest damage either to me or to any of those in whom I take an interest, I should nevertheless denounce it. Why? Because I am enthusiastic for morality, filled with the idea of morality; what is hostile to it I everywhere assail. Because in his mind theft ranks as abominable without any question, Proudhon, e. g., thinks that with the sentence "Property is theft" he has at once put a brand on property. In the sense of the priestly, theft is always a crime, or at least a misdeed." (EO: 100)

13 "Right - is a wheel in the head, put there by a spook." (EO: 275) 
anonymen Gesellschaft"), as well as the immaterial aspect in the sense of power (cf. EE: 181). Especially in the sense of power, the power to appropriate something and in the sense of control something, it is in the focus of Stirner's definition. There are approximated two levels of the confrontation. On the one side, it is a discussion of the contemporary image of property, which he criticises in his argumentation against the different streams of liberalism - et al. based on Proudhon - and on the other side it is a discussion of a term of property, which is focused on the power of the owner. This last point was broached as an issue by Bernd Kast in his thesis "Die Thematik des 'Eigners' in der Philosophie Max Stirners" with the following statement: "Eigentum des Eigners ist das vom Eigner potentiell Erreichbare und faktisch Erreichte" (Kast, 1979: 236) ${ }^{14}$. The right of ownership is negotiated by him as well as the idea of legislation. Anyhow, Stirner allocates with the two levels of Proudhon's definition of property:

"Das Eigentum, wie die bürgerlichen Liberalen es verstehen, verdient die Angriffe der Kommunisten und Proudhons: es ist unhaltbar, weil der bürgerliche Eigentümer wahrhaft nichts als ein Eigentumsloser, ein überall Ausgeschlossener ist. Statt dass ihm die Welt gehören könnte, gehört ihm nicht einmal der armselige Punkt, auf welchem er sich herumdreht.

Proudhon will nicht den propriétaire, sondern den possesseur oder usufruitier. Was heißt das? Er will, dass der Boden nicht einem gehöre; aber der Nutzen desselben - und gestände man ihm auch nur den hundertsten Teil dieses Nutzens, dieser Frucht, zu - der ist ja doch sein Eigentum, mit welchem er nach Belieben schalten kann. Wer nur den Nutzen eines Ackers hat, ist allerdings nicht der Eigentümer desselben; noch weniger, wer, wie Proudhon will, von diesem Nutzen so viel abgeben muss, als zu seinem Bedarf nicht notwendig erfordert wird; allein er ist der Eigentümer des ihm verbleibenden Anteils. Also negiert Proudhon nur dies und jenes Eigentum, nicht das Eigentum. Wenn Wir den Grundeigentümern den Grund nicht länger lassen, sondern Uns zueignen wollen, so vereinigen Wir Uns zu diesem Zwecke, bilden einen Verein, eine société, die sich zur Eigentümerin macht; glückt es Uns, so hören jene auf, Grundeigentümer zu sein. Und wie von Grund und Boden, so können Wir sie noch aus manchem an dern Eigentum hinausjagen, um es zu unserm Eigentum zu machen, zum Eigentum der - Erobernden. Die Erobernden bilden eine Sozietät, die man sich so groß denken kann, daß sie nach und nach die ganze Menschheit umfasst; aber auch die so genannte Menschheit ist als solche nur ein Gedanke (Spuk); ihre Wirklichkeit sind die

14 "The property of the owner is the potential gettable and the factual achievement." 
Einzelnen. Und diese Einzelnen werden als eine Gesamtmasse nicht weniger willkürlich mit Grund und Boden umgehen, als ein vereinzelter Einzelner, oder so genannter propriétaire. Auch so bleibt also das Eigentum bestehen, und zwar auch als , ausschließlich', indem die Menschheit, diese große Sozietät, den Einzelnen von ihrem Eigentum ausschließt (ihm vielleicht nur ein Stück davon verpachtet, $\mathrm{zu}$ Lehn gibt), wie sie ohnehin alles, was nicht Menschheit ist, ausschließt, z.B. die Tierwelt nicht zum Eigentum kommen lässt.” (EE: 253 f.) $)^{15}$

In this passage the fundament of Stirner's critique be can found. He condemns the differentiation of property and ownership, which is used by Proudhon. For him, the critique of property is missed out because Proudhon only criticise one special kind of property - the private property. Proudhon calls it the "propriété nue" and he criticises it from a moral point of view. In the argumentation of Stirner the differentiation of property and ownership, which is broached as the differentiation of private and collective property, appears as a shame. This shame cloud that the critique is not adjusted to property in general but it is adjusted only to the form of private property.

15 "Property as the civic liberals understand it deserves the attacks of the Communists and Proudhon: it is untenable, because the civic proprietor is in truth nothing but a property-less man, one who is everywhere shut out. Instead of owning the world, as he might, he does not own even the paltry point on which he turns around. Proudhon wants not the propriétaire but the possesseur or usufruitier. What does that mean? He wants no one to own the land; but the benefit of it - even though one were allowed only the hundredth part of this benefit, this fruit - is at any rate one's property, which he can dispose of at will. He who has the benefit of a field is assuredly not the proprietor of it; still less he who, as Proudhon would have it, must give up so much of this benefit as is not required for his wants; but he is the proprietor of the share that is left him. Proudhon, therefore, denies only such and such property, not property itself. If we want no longer to leave the land to the landed proprietors, but to appropriate it to ourselves, we unite ourselves to this end, form a union, a société, that makes itself proprietor; if we have good luck in this, then those persons cease to be landed proprietors. And, as from the land, so we can drive them out of many another property yet, in order to make it our property, the property of the - conquerors. The conquerors form a society which one may imagine so great that it by degrees embraces all humanity; but so-called humanity too is as such only a thought (spook); the individuals are its reality. And these individuals as a collective (mass will treat land and earth not less arbitrarily than an isolated individual or so-called propriétaire. Even so, therefore, property remains standing, and that as exclusive" too, in that humanity, this great society, excludes the individual from its property (perhaps only leases to him, gives his as a fief, a piece of it) as it besides excludes everything that is not humanity, e. g. does not allow animals to have property." (EO, 328p.) 
In this coherence Stirner mentions the question of the relation of the individual to the collective again. As in other political and philosophical streams of his time, Proudhon's critique is in the point of view of Stirner not penetrative enough. It is only focussed on a partial aspect, which looses the sight of general context of the problem. It is only focussed on a Spuk, which leads to a disempowerment of the individual. He continues his critique with the following words:

"Proudhon konnte sein weitläufiges Pathos sparen, wenn er sagte: Es gibt einige Dinge, die nur Wenigen gehören, und auf die Wir übrigen von nun an Anspruch oder - Jagd machen wollen. Lasst sie Uns nehmen, weil man durch's Nehmen zum Eigentum kommt, und das für jetzt noch uns entzogene Eigentum auch nur durchs Nehmen an die Eigentümer gekommen ist. Es wird sich besser nutzen lassen, wenn es in Unser Aller Händen ist, als wenn die Wenigen darüber verfügen. Assoziieren wir Uns daher zu dem Zwecke dieses Raubes (vol). - Dafür schwindelt er Uns vor, die Sozietät sei die ursprüngliche Besitzerin und die einzige Eigentümerin von unverjährbarem Recht; an ihr sei der so genannte Eigentümer zum Diebe geworden. ( $L a$ propriété c'est le vol); wenn sie nun dem dermaligen Eigentümer sein Eigentum entziehe, so raube sie ihm nichts, da sie nur ihr unverjährbares Recht geltend mache. [...] Proudhon, wie die Kommunisten, kämpfen gegen den Egoismus. Darum sind sie Fortsetzungen und Konsequenzen des christlichen Prinzips, des Prinzips der Liebe, der Aufopferung für ein Allgemeines, ein Fremdes. Sie vollenden z.B. im Eigentum nur, was längst der Sache nach vorhanden ist, nämlich die Eigentumslosigkeit des Einzelnen. Wenn es im Gesetz heißt: Ad reges potestas omnium pertinet, ad singulos proprietas; omnia rex imperio possidet, singuli dominio, so heißt dies: Der König ist Eigentümer, denn Er allein kann über "Alles" verfügen, schalten, er hat potestas und imperium darüber. Die Kommunisten machen dies klarer, indem sie jenes imperium der "Gesellschaft Aller" übertragen. Also: Weil Feinde des Egoismus, darum sind sie - Christen, oder allgemeiner: religiöse Menschen, Gespenstergläubige, Abhängige, Diener irgend eines Allgemeinen (Gottes, der Gesellschaft usw.). Auch darin gleicht Proudhon den Christen, dass er dasjenige, was er den Menschen abspricht, Gott beilegt. Ihn nennt er (z. B. Seite 90) den Propriétaire der Erde. Hiermit beweist er, dass er den Eigentümer als solchen nicht wegdenken kann; er kommt zuletzt auf einen Eigentümer, verlegt ihn aber ins Jenseits" (EE: 254 f.) ${ }^{16}$

16 "Proudhon might spare his prolix pathos if he said: "There are some things that belong only to a few, and to which we others will from now on lay claim or - 
In this longer passage the basic aspects of Stirner's thought can be found. He concretises his critique of Proudhon with regard to the negation of the interests of the individual as well as focussing on the concept of legislation. The communist-orientated belief, that the private property should be transformed into collective property, is abject from Stirner as a negotiation of the egoism, a transformation to "Eigentumslosigkeit des Eigners" ("ownershipless of the owner"). Proudhon is in this case part of a serial of thinkers who prefers the universal term to the individual interests - Communism or Christianity.

The critiques of Proudhon manifests in the confrontation with the term of legislation.

"Das Privateigentum lebt von der Gnade des Rechts. Nur im Rechte hat es seine Gewähr - Besitz ist ja noch nicht Eigentum, er wird erst "das Meinige" durch Zustimmung des Rechts -; es ist keine Tatsache, nicht un fait, wie Proudhon meint, sondern eine Fiktion, ein Gedanke. Das ist das Rechtseigentum, rechtliches Eigentum, garantiertes Eigentum. Nicht durch Mich ist es mein, sondern durch's - Recht." (EE: 256$)^{17}$

siege. Let us take them, because one comes to property by taking, and the property of which for the present we are still deprived came to the proprietors likewise only by taking. It can be utilized better if it is in the hands of us all than if the few control it. Let us therefore associate ourselves for the purpose of this robbery (vol)." - Instead of this, he tries to get us to believe that society is the original possessor and the sole proprietor, of imprescriptible right; against it the so-called proprietors have become thieves (La propriété c'est le vol); if it now deprives of his property the present proprietor, it robs him of nothing, as it is only availing itself of its imprescriptible right. [...] Proudhon, like the Communists, fights against egoism. Therefore they are continuations and consistent carryings-out of the Christian principle, the principle of love, of sacrifice for something general, something alien. They complete in property, e. g., only (331) what has long been extant as a matter of fact - to wit, the propertylessness of the individual. When the laws says, Ad reges potestas omnium pertinet, ad singulos proprietas; omnia rex imperio possidet, singuli dominio, this means: The king is proprietor, for he alone can control and dispose of "everything", he has potestas and imperium over it. The Communists make this clearer, transferring that imperium to the "society of all". Therefore: Because enemies of egoism, they are on that account - Christians, or, more generally speaking, religious men, believers in ghosts, dependents, servants of some generality (God, society, etc.). In this too Proudhon is like the Christians, that he ascribes to God that which he denies to men. He names him (e. g. page 90) the Propriétaire of the earth. Herewith he proves that he cannot think away the proprietor as such; he comes to a proprietor at last, but removes him to the other world." (EO: 330)

17 "Private property lives by grace of the law." (EO: 332) 
From Stirner's position the question about private property - in the sense of "pure property" - is linked to legislation. He picks up the differentiation from Proudhon between "ownership" and "property". He focuses on the second level of the term of Proudhon. The meaning of "ownership" is for Stirner clear; in this case he agrees with Proudhon. He unmasks the property in the meaning of "right of ownership" as a fix idea, because it is based on the legislation. The term of property how Stirner tries to show differs from his own. His own term of property is based on power, especially the disposal of something. However, Proudhon's term of property is based on the legislation, what means that it is based on a foreign authority which is beyond the concrete individual. The term is basically focussed in the use of Proudhon on the material side of it. He contrasts it with his own term of property, which is based on the idea of power, especially the disposal of something.

An answer to the problem of the term property can be read in the following passage:

"Genug, die Eigentumsfrage lässt sich nicht so gütlich lösen, als die Sozialisten, ja selbst die Kommunisten träumen. Sie wird nur gelöst durch den Krieg Aller gegen Alle. Die Armen werden nur frei und Eigentümer, wenn sie sich - empören, emporbringen, erheben. Schenkt ihnen noch so viel, sie werden doch immer mehr haben wollen; denn sie wollen nichts Geringeres, als dass endlich - nichts mehr geschenkt werde" (EE, 264) ${ }^{18}$

Another point which should be mentioned in this context is Proudhon's critique of the term of property in the works of the philosopher Destrutt de Tracy (1754-1836). He argues against him in his work “Qu'est-ce que la proprieté?". Tracy's term of property is very similar to the use of Stirner. Proudhon quotes him with the words:

"L'idée de propriété ne peut être fondée sur l'idée de personnalité. Dès que naît l'idée de propriété, elle naît dans toute sa plénitude nécessairement et inévitablement. Dès qu'un individu connaît son moi, sa personne morale, sa capacité de jouir, souffrir, agir, nécessairement il voit aussi que ce moi est propriétaire exclusif du corps qu'il anime, des organes, de leurs forces et facultés, etc. Il fallait bien qu'il y eût une propriété naturelle et nécessaire, puisqu'il en existe d'artificielles et conventionnelles; car il ne peut y avoir rien dans l'art qui n'ait son principe dans la nature" (Proudhon, 1841: 58f.).

18 "In short, the property question cannot be solved so amicably as the Socialists, yes, even the Communists, dream. It is solved only by the war of all against all. The poor become free and proprietors only when they rise." (OP: 343) 
Afterwards he criticises this:

"Admirons la bonne foi et la raison des philosophes. L'homme a des propriétés, c'est-à-dire, dans la première acception du terme, des facultés; il en a la propriété, c'est-à-dire, dans la seconde acception, le domaine: il a donc la propriété de la propriété d'être propriétaire. Combien je rougirais de relever de telles niaiseries, si je ne considérais ici que l'autorité de Destutt de Tracy!" (Proudhon, 1841: 59)

Stirner hasn't commented this passage. Proudhon's critique of Tracy could also be applied to his own term of property.

\section{Conclusion}

It could be declared that the Stirnerian critique of Proudhon is more than "only" a critique of possession and antagonism against the individual - what it is often reduced in literature. Stirner tries to disprove the specific construction of Proudhon's thinking - the differentiation between "property" and "right of ownership". In doing this refusal the specification of Stirner's term can be seen. The definition of property which is used by Proudhon can be seen as one integral part of the idea of property of Stirner. The other level, which defines property as private property, is in the terminology of Stirner a fix idea, which is based on wrong assumptions. The property by Proudhon - in the meaning of pure property - is based on components, which are beyond the individual. There are foreign elements. From this point of view, Proudhon can declare, that property is theft. In the sense of Stirner this is no property (Eigentum) because the individual has no disposal of it. Stirner writes in "Der Einzige und sein Eigentum":

"Meine Macht ist mein Eigentum.

Meine Macht gibt Mir Eigentum.

Meine Macht bin Ich selbst und bin durch sie mein Eigentum" (EE: $191)^{19}$.

All in all, it shows, that the critique of Proudhon is not simply a refusal of the Proudhonian system, but a confrontation about a - in the eyes of Stirner - wrong differentiation of the term. By means of the critique Stirner creates his own position about property and legislation. In

19 "My power is my property.

My power gives me property.

My power am I myself, and through it am I my property." (EO: 242) 
the confrontation with the Proudhonian concept his own concept of the owner becomes clear.

\section{Literature}

Bauer, Edgar (1844) Proudhon, in: Allgemeine Literatur-Zeitschrift, hrsg. von Bruno Bauer, Nr. 5 April 1844. Egbert Bauer, Charlottenburg, 37-52.

Bock, Hans-Manfred (1991): Pierre-Joseph Proudhon, in: Euchner, Walter (Edit.): Klassiker des Sozialismus, 1. Band,'. C.H. Beck, München, 97-109.

Cingolani, Patrick (1992): Max Stirner: “j'ai fondé ma cause sur rien”, in: Ecole des hautes études et sciences sociales: Les travaux de l'atelier Proudhon 11: Les anarchistes et Proudhon, Paris, 17-28.

Cohn, Alfons Fedor (1896): Vorwort des Übersetzers, in: Was ist eigentlich das Eigentum? Eine Denkschrift. Untersuchungen über den Ursprung und die Grundlagen des Rechts und der Herrschaft. Zack, Berlin, V-XX.

Diehl, Karl (1968): Pierre Joseph Proudhon. Seine Lehre und sein Leben. 3 Abteilungen in einem Band, Neudruck der Ausgabe Jena 1888-1896. Scientia, Aalen.

Forest, Herve-Marie (1979): Marx au miroir de Stirner. Editions Le Sycomore, Paris.

Helms, Hans G. (1966): Die Ideologie der anonymen Gesellschaft. Du Mont, Köln.

Kast, Bernd (1979): Die Thematik des "Eigners" in der Philosophie Max Stirners. Sein Beitrag zur Radikalisierung der anthropologischen Fragestellung. Bouvier Verlag Herbert Grundamnn Bonn [Zugl. Univ.-Diss., Mainz, 1977].

Laska, Bernd A. (1993): Max Stirner, in: Lexikon der Anarchie. Schwarzer Nachtschatten, Bösdorf.

Mackay, John Henry (1977): Max Stirner. Sein Leben und sein Werk, Verlag der Mackay-Gesellschaft, Freiburg i.Br.

Marx, Karl (1972): Das Elend der Philosophie, in: Marx, Karl / Engels, Friedrich: Werke, Band 4, hrsg. vom Institut für Marxismus-Leninismus beim ZK der SED. Dietz, Berlin, 63 - 182.

Marx, Karl / Engels, Friedrich (1962): Die heilige Familie. Oder: Kritik der kritischen Kritik, Bruno Bauer und Konsorten, in: Marx, Karl / Engels, Friedrich: Werke, Band 19, hrsg. vom Institut für Marxismus-Leninismus beim ZK der SED. Dietz, Berlin, 3-224.

Ders. (1969): Die deutsche Ideologie, in: Marx, Karl / Engels, Friedrich: Werke, Band 3, hrsg. vom Institut für Marxismus-Leninismus beim ZK der SED. Dietz, Berlin, $9-530$.

Proudhon, Pierre-Joseph (1841): De la Création de l'ordre dans l'humanité ou principes d'organisation politique. Paris a la libraire de Prevot, Besançon. [Von der Schaffung der Ordnung in der Menschheit oder: Prinzipien der politischen Organisation.] 
Ders. (1843): Qu'est-ce que la propriété? Ou recherches sur le principe du droit et du gouvernement. Paris a la libraire de Prevot, Besançon.

Ders. (1896): Was ist eigentlich das Eigentum? Eine Denkschrift. Untersuchungen über den Ursprung und die Grundlagen des Rechts und der Herrschaft. Zack Berlin.

Ders. (1846): Système des contradictions économiques ou Philosophie de la misère. Guillaumin et cie. Libraires Paris.

Ders. (1847): Die Widersprüche der National-Oekonomie oder die Philosophie der Not. Otto Wigand, Leipzig.

Ders.(1849): Les Confessions d'un révolutionnaire pour servir à l'histoire de la Révolution de Février. La Voix du peuple, Paris.

Ders. (1850): Bekenntnisse eines Revolutionärs, hrsg. von Arnold Ruge. Leipziger Verlagsbüro, Leipzig.

Roemheld, Lutz (1993): Pierre Joseph Proudhon, in: Lexikon der Anarchie. Schwarzer Nachtschatten Bösdorf.

Senft, Gerhard (1988): Der Schatten des Einzigen. Die Geschichte des Stirnerschen Individual-Anarchismus. Monte Verita, Wien.

Skirda, Alexandre (1987): Autonomie individuelle et force collective. Les anarchistes et l'organisation de Proudhon à nos jours. A.S., Paris.

Stirner, Max (2009/1844): Der Einzige und sein Eigentum [EE]. Ausführlich kommentierte Studienausgabe, hrsg. und mit Nachwort von Bernd Kast. Karl Alber, Freiburg/München.

Ders. (1907): The Ego and its Own [EO]. Translated from the German by Steven T. Byington. With an Introduction by J. L. Walker, Benj. Tucker New York.

Weitling, Wilhelm (1842): Garantien der Harmonie und Freiheit. Selbstverlag Vivis.

Woodcock, George (1956): Pierre-Joseph Proudhon. The Macmillan Company, New York.

\begin{abstract}
Max Stirners critique of Proudhon's thoughts in the context of their young Hegelian reception

Very early on, the works and ideas of the French socialist P.J.-Proudhon were discussed in the circle of the German young Hegelians. Also, Max Stirner mentioned him several times in Der Einzige und sein Eigentum. His critique of Proudhon's thoughts is very important for his own definition and confrontation with the concept of property. The article analyses the different levels of his examination with this concept.
\end{abstract}

